\title{
Short Communication: Cystic Fibrosis "Factor(s)": Present Also in Sera of Shwachman's Pancreatic Insufficiency
}

\author{
G. BANCHINI, J. T. HARRIES, P. J. MILlA, D. P. R. MULlER, E. ROMA, AND J. H. TRIPP(33) \\ Department of Child Health, Institute of Child Health, London W. C. I., England
}

\begin{abstract}
Summary
Using an in vivo closed-loop technique in rat jejunum, we have confirmed previous in vitro studies that cystic fibrosis (CF) serum inhibits water, sodium, and glucose absorption and transmural potential difference. CF heterozygote serum or sera from children with diarrhoeal disorders not associated with exocrine pancreatic insufficiency had no effect on transport. Sera from patients with Shwachman's syndrome and exocrine pancreatic insufficiency had identical effects to $C F$ serum. These results challenge the specificity of the CF "factor."
\end{abstract}

\section{Speculation}

\section{PANCREATIC-RELATED FACTORS}

The pancreas may modulate small intestinal absorption of water, electrolytes, and glucose via an humoral pathway. In exocrine pancreatic insufficiency, there could.be a deficiency of a normal serum factor which stimulates absorption or, alternatively, a factor which inhibits absorption could be present.

Cystic fibrosis (CF) is the commonest, lethal, genetically determined disorder encountered in Caucasians, yet the primary defect has not been defined. There is, however, increasing evidence that abnormalities of water and electrolyte transport may underlie the dysfunction of exocrine glands in this disorder, and CF "factor(s)" have been implicated as being primary in pathogenesis (10-12). Such factor(s) have been reported in sweat, saliva, and serum ( 2 , $5,7,15,16,18,22)$ using a variety of in vitro techniques.

Araki et al. (2) demonstrated that homozygous and heterozygous CF serum inhibited glucose-stimulated short-circuit current in rat jejunum in vitro, suggesting the presence of a specific factor(s) which inhibited glucose-dependent sodium transport.

In this study, we have extended the observations of Araki et al. (2) in an in vivo model in the rat in an attempt to elucidate the mechanisms and specificity of the effects of $C F$ serum on jejunal transport. These studies have in part been reported in abstract form $(3,20)$.

\section{SUBJECTS}

Informed consent was obtained from all patients and their parents.

In part one, serum from eight patients with $\mathrm{CF}$ (at least two positive sweat tests in duplicate) and exocrine pancreatic insufficiency (EPI), aged 2 to 12 years (median, 9 years) were studied. Control sera were from healthy adults.

In part two, nine patients with CF and EPI aged 8 to 14 years (median, 11 years) 14 CF parents, five patients with Shwachman's syndrome aged $2 \frac{1}{2}$ to 10 years (median, 3 years) and nine patients with other diarrhoeal states (e.g., "irritable bowel syndrome," cow's milk protein intolerance, congenital chloride diarrhoea, or protracted diarrhoea of undetermined cause) aged 6 months to 7 years (median, 1 year) were studied; pancreatic function was formally assessed in five of the latter group and found to be normal. In the second series, control sera was always obtained from one of us. Six of nine CF patients and four of nine with other diarrhoeal disorders, but none of the other groups, were receiving antibiotics whereas all the $\mathrm{CF}$ and Shwachman patients were receiving standard pancreatic supplements. Shwachman's syndrome was diagnosed on the basis of a combination of EPI, impaired growth unrelated to dietary intake and/or malabsorption, intermittent neutropenia, defective neutrophil mobility, and skeletal abnormalities as outlined by Aggett et al. (1).

\section{MATERIALS AND METHODS}

Pancreatic function was assessed using a test meal stimulus (17). Blood was collected by venepuncture using siliconised plastic syringes and glass vials. Separated sera were stored at $-20^{\circ} \mathrm{C}$ (first part) or $-70^{\circ} \mathrm{C}$ (second part) for 20 to 24 days.

The effects of sera were studied using an established closed loop technique $(14,24)$. In the first part of the study, two closed loops of proximal jejunum 10 to $15 \mathrm{~cm}$ long were constructed in male Wistar rats weighing 200 to $250 \mathrm{~g}$, and undiluted test and control sera were placed in the first or second loop in a randomised fashion for a $30-\mathrm{min}$ period. Volume of serum was 0.5 to $1.0 \mathrm{ml} /$ loop and was such as to produce a similar and moderate degree of dilatation in each loop. Net water, sodium, and glucose absorption were expressed as percentage of absorption per $30 \mathrm{~min}$. At the end of each experiment, mucosa was scraped off at $4^{\circ} \mathrm{C}$, snap frozen on cardice, and stored at $-70^{\circ} \mathrm{C}$ until assayed for $\left(\mathrm{Na}^{+}-\mathrm{K}^{+}\right)$ATPase by methods described elsewhere (26).

In the second part of the study, the incubation period was 15 min. Standardisation of the initial serum concentration of glucose to $10 \mathrm{mmoles} /$ liter (by adding glucose after initial serum assay) on the day of the experiment enabled calculation of absorptive rates as $\mathrm{ml}$ water or mmoles solute per $\mathrm{g}$ wet weight of gut per min, using standard formulae $(14,24)$. In both parts of the study, results were compared statistically by paired $t$ tests using control and test loops in the same animal.

Table 1. Results of first part of study

\begin{tabular}{lccc}
\hline & Controls (7) & $P$ & CF (7) \\
\hline Water & $28.2 \pm 4.3^{1}$ & $<0.05$ & $13.7 \pm 1.7$ \\
Sodium & $30.9 \pm 4.5$ & $<0.05$ & $15.0 \pm 2.9$ \\
Glucose & $88.5 \pm 4.8$ & $<0.02$ & $53.5 \pm 8.9$ \\
PD $(\mathrm{mV})$ & $8.1 \pm 0.6$ & $<0.005$ & $6.9 \pm 8.9$ \\
$\left(\mathrm{Na}^{+}-\mathrm{K}^{+}\right)$-ATPase $(\mu$ moles/ & $5.1 \pm 0.6$ & $\mathrm{NS}^{2}$ & $5.1 \pm 0.5$ \\
$\quad$ mg protein $\left.^{-1} / \mathrm{hr}^{-1}\right)$ & & & \\
\hline
\end{tabular}

\footnotetext{
${ }^{1}$ Mean \pm S.E.

${ }^{2}$ N.S., not significant.
} 
Table 2. Results of second part of study

\begin{tabular}{|c|c|c|c|c|c|c|c|c|c|}
\hline \multirow[b]{3}{*}{ Subjects } & \multicolumn{9}{|c|}{ Net absorption } \\
\hline & \multicolumn{3}{|c|}{$\begin{array}{c}\text { Water } \\
(\mathrm{ml} / \mathrm{g} \cdot \text { wet } \mathrm{wt} / \mathrm{min})\end{array}$} & \multicolumn{3}{|c|}{$\begin{array}{c}\text { Sodium } \\
(\mathrm{mmoles} / \mathrm{g} \cdot \text { wet } \mathrm{wt} / \mathrm{min})\end{array}$} & \multicolumn{3}{|c|}{$\begin{array}{c}\text { Glucose } \\
\text { (mmoles } / \mathrm{g} \cdot \text { wet } \mathrm{wt} / \mathrm{min})\end{array}$} \\
\hline & Controls & & Tests & Controls & & Tests & Controls & & Tests \\
\hline $\mathrm{CF}(9)^{1}$ & $0.78 \pm 0.08^{2}$ & $P<0.005$ & $0.54 \pm 0.03$ & $110.0 \pm 13.0$ & $P<0.005$ & $76.0 \pm 3.0$ & $16.9 \pm 1.2$ & $P<0.001$ & $12.4 \pm 0.9$ \\
\hline Shwachman's (15) & $0.74 \pm 0.08$ & $P<0.02$ & $0.58 \pm 0.05$ & $101.0 \pm 12.0$ & $P<0.05$ & $77.0 \pm 10.0$ & $17.3 \pm 2.1$ & $P<0.02$ & $13.2 \pm 1.4$ \\
\hline Others (9) & $0.81 \pm 0.03$ & NS & $0.82 \pm 0.04$ & $113.0 \pm 4.0$ & NS & $113.0 \pm 6.0$ & $19.8 \pm 0.5$ & NS & $20.6 \pm 1.0$ \\
\hline
\end{tabular}

${ }^{1}$ Numbers in parentheses, number of subjects studied.

${ }^{2}$ Mean \pm 1 S.E.

${ }^{3} \mathrm{NS}$, not significant.

\section{RESULTS}

Table 1 shows the results of the first part of the study. CF sera caused a significant reduction in the net absorption of water $(P$ $<0.05)$, sodium $(P<0.05)$, glucose $(P<0.02)$, and PD $(P<$ $0.005)$ compared with control sera, but $\left(\mathrm{Na}^{+}-\mathrm{K}^{+}\right)$-ATPase activity was not affected.

Table 2 shows the results of the second part of the study. Net water, sodium, and glucose absorption was significantly reduced in both the CF patients $(P<0.005, P<0.005$, and $P<0.001$, respectively) and in those with Shwachman's syndrome $(P<0.02$, $P<0.05$, and $P<0.02$, respectively), but sera from CF heterozygotes and children with other diarrhoeal states were indistinguishable from control serum.

No effects of age or sex were detectable in any group. In neither the CF nor the other diarrhoeal diseases group was there any differences related to antibiotic administration.

\section{DISCUSSION}

Our in vivo findings that $\mathrm{CF}$ serum inhibits small intestinal absorption of water, sodium and glucose, as well as PD agree with the in vitro electrical findings of Araki et al. (2) and the inhibitory effect of CF plasma on carbohydrate absorption reported by Brown et al. (5). Will et al. (28), comparing CF and normal sera with a buffer solution in an in vitro brush border vesicle preparation, were unable to demonstrate differences between the two sera; both markedly inhibited transport as compared to the buffer. This discrepancy may be due to the major differences in experimental models. Variation in the concentration of glucose in their sera might be expected to affect the findings.

The inhibitory effects of CF serum on jejunal absorption of water, sodium, and glucose and on PD might be explained on the basis of reduced mucosal $\left(\mathrm{Na}^{+}-\mathrm{K}^{+}\right)$-ATPase activity because this enzyme plays a key role in electrogenic glucose-coupled sodium absorption (23). Feig et al. (13) assayed $\left(\mathrm{Na}^{+}-\mathrm{K}^{+}\right)$-ATPase in CF erythrocytes, and Quissell and Pitot (19) assayed ouabain-binding sites in CF fibroblasts, but neither study demonstrated differences compared to their control data. Cole and Sella (7), however, showed that $\mathrm{CF}$ saliva inhibited erthrocyte $\left(\mathrm{Na}^{+}-\mathrm{K}^{+}\right)$-ATPase activity. We were unable to show any effect of $\mathrm{CF}$ serum on mucosal $\left(\mathrm{Na}^{+}-\mathrm{K}^{+}\right)$-ATPase when the enzyme was assayed under conventional in vitro conditions. This does not exclude a more subtle change in activity which might have been detected using a more physiologic assay (21). Another possible site of action of stimulation or inhibitory factors on glucose-coupled sodium transport could be at the brush border level of the enterocyte (8).

In contrast to Araki et al. (2), and Brown et al. (5), we have been unable to demonstrate any effect induced by heterozygote $\mathrm{CF}$ serum. This may be due to a lesser sensitivity of our in vivo system, or, alternatively, the present assay may be detecting another factor(s). Such discrepant results have in fact been the rule rather than the exception in previous studies of the CF factor(s)
$(4,9,25,27)$ and may reflect not only the experimental models used but also the fact that many studies have been inadequately controlled.

In an attempt to clarify the specificity of the phenomenon, our study included two further groups of patients with diarrhoeal disease: one of patients with Shwachman's syndrome with EPI and a second miscellaneous group of patients without evidence of EPI. The effect of CF and Shwachman's serum on transport were very similar, whereas the miscellaneous group and CF heterozygotes were indistinguishable from the normal "controls." These findings suggest that the phenomenon is related to EPI rather than to the CF gene itself or to the diarrhoea per se.

Although we did not find that antibiotic therapy had any effect on absorption rates, we are unable to definitely exclude an effect of pancreatic supplements because both the CF and Shwachman groups were receiving these. We suggest that it is unlikely that the "foreign" protein of animal-derived pancreatic supplements would be absorbed in significant quantities from the gastrointestinal tract.

In general, previous workers have suggested that the effects of $\mathrm{CF}$ serum on various biologic systems are due to the presence of an inhibitory factor (10-12). Chou and Nadler (6), however, provided evidence suggesting the absence of a normal stimulatory factor. Because the factor we have demonstrated is not specific to CF but occurs in another type of EPI, it seems likely that its origin may be related to EPI rather than to the underlying disorder. In this context, it would be of particular interest to study CF patients who do not have EPI.

Our data are compatible with the thesis that either the pancreas elaborates a serum factor(s) which modulates small intestinal function and that in EPI there is a deficiency of a normal stimulatory factor(s) or, alternatively, that there are abnormal or increased inhibitory factor(s) associated with a diseased (nonfunctioning) exocrine pancreas. Further studies are required to test this hypothesis. Our results also challenge the specificity of the socalled CF factor(s) which have been previously reported.

\section{REFERENCES AND NOTES}

1. Aggett, P. J., Cavanagh, N. P. C., Matthew, D. J., Pincott, J. R., Sutcliffe, J., and Harries, J. T.: Shwachman's syndrome: a review of 21 cases. Arch. Dis. Child., 55: 331 (1980).

2. Araki, H., Field, M., and Shwachman, H.: A new assay for cystic fibrosis factor: effects of sera from patients with cystic fibrosis in the in vitro electrical properties of rat jejunum. Pediatr. Res., 9: 932 (1975).

3. Banchini, G., Tripp, J. H., Roma, E., Milla, P. J., Muller, D. P. R., and Harries, J. T.: The effect of serum from patients with pancreatic insufficiency (PI) on jejunal transport in the rat jejunum in vivo. Gut, 19: A958 (1978).

4. Benke, P. J., Erbstoeszer, M., and Pitot, H. C.: Transport of labelled compounds in control and cystic fibrosis cells in vitro. Lancet, $l: 182$ (1972).

5. Brown, G. A., Oshin, A., Goodchild, M. C., and Anderson, C. M.: Inhibition of sugar transport by plasma from cystic fibrosis patients. Lancet, 2: 639 (1971).

6. Chou, L., and Nadler, H.: Absence of a serum factor in patients with cystic fibrosis. Pediatr. Res., 10: 176 (1976).

7. Cole, C. H., and Sella, G.: Inhibition of ouabain sensitive ATPase by the saliva 
of patients with cystic fibrosis of the pancreas. Pediatr. Res., 9: 763 (1975).

8. Crane, R. K.: Intestinal absorption of glucose. Biomembranes, 4A: 541 (1974).

9. Di Sant'Agnese, P. A., and Darling, R. C.: Cystic Fibrosis of the Pancreas. The Child with Disabling Illness. ed. 1. In: Downey and Low (W. B. Saunders Company, Philadelphia, 1974).

10. Di Sant'Agnese, P. A., and Davis, P. B.: Research in cystic fibrosis. I. N. Engl. J Med., 295: 481 (1976).

11. Di Sant'Agnese, P. A., and Davis, P. B.: Research in cystic fibrosis. II. N. Engl. J. Med., 295: 534 (1976).

12. Di Sant'Agnese, P. A. and Davis, P. B.: Research in cystic fibrosis. III. N. Engl. J. Med., 295: 597 (1976).

13. Feig, S. A., Segel, G. B., Kern, K. A., Osher, A. B., and Schwartz, R. H. Erythrocyte transport function in cystic fibrosis. Pediatr. Res., 8: 594 (1974).

14. Harries, J. T., and Sladen, G.: The effects of different bile salts on the absorption of fluid, electrolytes and monosaccharides in the small intestine of the rat in vivo. Gut, 13: 596 (1972)

15. Kaiser, D., Drack, E., and Rossi, E.: Inhibition of net sodium transport in single sweat glands by sweat of patients with cystic fibrosis of the pancreas. Pediatr. Res., 5: 167 (1971).

16. Mangos, J. A., McSherry, N. R., and Benke, P. J. A.: A sodium transport inhibitory factor in the saliva of patients with cystic fibrosis of the pancreas. Pediatr. Res., 1: 436 (1967)

17. McCollum, J. P. K., Muller, D. P. R., and Harries, J. T.: Test meal for assessing intraluminal phase of absorption in childhood. Arch. Dis. Child., 52: 887 (1977).

18, Morin, C. L., Desjeux, J. F., and Authier, L.: Effect of saliva and serum from patients with cystic fibrosis on intestinal uptake of amino acids in rat. Biomedicine, 19: 133 (1973).

19. Quissell, D. O., and Pitot, H. C.: Number of ouabain binding sites in fibroblasts from normal subjects and patients with cystic fibrosis. Nature (Lond.), 247 . 115 (1974)

20. Roma, E., Milla, P. J., Tripp, J. H., and Harries, J. T.: Inhibition of jejunal transport in rat jejunum by cystic fibrosis (CF) serum. Arch. Dis. Child., 53. $263 \mathrm{~A}$ (1978).
21. Schmidt, W., Schmid, J., Schmid, H., and Dubach, U. C.: Sodium and potassium activated ATPase. A possible target of aldosterone. J. Clin. Invest, 55: 655 (1975).

22. Schultz, 1. J.: Micropuncture studies of the sweat formation in cystic fibrosis patients. J. Clin. Invest., $48: 1470$ (1969).

23. Schwartz, A., Lindenmayer, G. E., and Allen, J. C.: The sodium-potassiumadenosinetriphosphatase: pharmacological, physiological and biochemical aspects. Pharmacol. Rev., 27: 1 (1975).

24. Sladen, G. E., and Harries, J. T.: Studies on the effects of unconjugated dihydroxy bile salts on rat small intestinal function in vivo. Biochem. Biophys. Acta, 288: 443 (1972).

25. Taussig, L. M., and Gardner, J. D.: Effects of salvia and plasma from cystic fibrosis patients on membrane transport. Lancet, 1: 1367 (1972).

26. Tripp, J. H., Muller, D. P. R., and Harries, J. T.: Mucosal $\left(\mathrm{Na}^{+}-\mathrm{K}^{+}\right)$-A.TPase and adenylate cyclase activities in children with toddler diarrhea and the postenteritis syndrome. Pediatr. Res., 14: 1382 (1980).

27. Wood, R. E., and Di Sant'Agnese, P. A.: Bioassays of cystic fibrosis factor. Lancet, 2: 1452 (1973)

28. Will, P. C., Boat, T. F., and Hopfer, U.: Evidence against a specific effect of serum from patients with cystic fibrosis on sodium-dependent glucose transport in the rat jejunum. Pediatr. Res., 13: 1129 (1979).

29. The present address of Dr. G. Banchini is: Department of Paediatrics, Universita' degli Studi, O.O.R.R., Via Gramsci, 43100, Parma, Italy.

30. The present address of Dr. E. Roma is: First Department of Paediatrics, University of Athens, Aghia Sophia Children's Hospital, Athens 608, Greece.

31. The present address of Dr. J. H. Tripp is: Paediatric Research Unit, Royal Devon and Exeter Hospital (Heavitree), Gladstone Road, Exeter, Devon, England.

32. The authors are grateful to the Cystic Fibrosis Research Trust for financial support.

33. Requests for reprints should be addressed to: Dr. J. H. Tripp, Paediatric Research Unit, Royal Devon and Exeter Hospital (Havitree), Gladstone Road, Exeter, Devon, England.

34. Received for publication November 27, 1979

35. Accepted for publication October 23, 1980 